\title{
The sea cliff at Dwasieden: soft-sediment deformation structures triggered by glacial isostatic adjustment in front of the advancing Scandinavian Ice Sheet
}

\author{
Małgorzata Pisarska-Jamroży ${ }^{1}$, Szymon Belzyt $^{1}$, Andreas Börner ${ }^{2}$, Gösta Hoffmann $^{3}$, Heiko Hüneke ${ }^{4}$, \\ Michael Kenzler ${ }^{4}$, Karsten Obst ${ }^{2}$, Henrik Rother ${ }^{5}$, Holger Steffen ${ }^{6}$, Rebekka Steffen ${ }^{6}$, and Tom van Loon ${ }^{7}$ \\ ${ }^{1}$ Geological Institute, Adam Mickiewicz University, B. Krygowskiego 12, 61-680 Poznań, Poland \\ ${ }^{2}$ State Authority of Environment, Nature Conservation and Geology Mecklenburg-Western Pomerania, Goldberger 12, \\ 18273 Güstrow, Germany \\ ${ }^{3}$ Steinmann Institute for Geology, Bonn University, Nussallee 8, 53115 Bonn, Germany \\ ${ }^{4}$ Institute of Geography and Geology, University of Greifswald, F.-L. Jahn 17a, 17487 Greifswald, Germany \\ ${ }^{5}$ Landesamt für Geologie und Bergwesen, Sachsen Anhalt, Dezernat Landesaufnahme und Analytik, Köthener 38, \\ 06118 Halle, Germany \\ ${ }^{6}$ Geodetic Infrastructure, Lantmäteriet, Lantmäterigatan 2C, 80182 Gävle, Sweden \\ ${ }^{7}$ College of Earth Science and Engineering, Shandong University of Science and Technology, Qingdao 266590, \\ Shandong, China
}

Correspondence: $\quad$ Małgorzata Pisarska-Jamroży (pisanka@amu.edu.pl)

Relevant dates: $\quad$ Published: 15 August 2019

How to cite: $\quad$ Pisarska-Jamroży, M. G., Belzyt, S., Börner, A., Hoffmann, G., Hüneke, H., Kenzler, M., Obst, K., Rother, H., Steffen, H., Steffen, R., and van Loon, T.: The sea cliff at Dwasieden: soft-sediment deformation structures triggered by glacial isostatic adjustment in front of the advancing Scandinavian Ice Sheet, DEUQUA Spec. Pub., 2, 61-67, https://doi.org/10.5194/deuquasp-2-61-2019, 2019.

Abstract:

Isostatic response of the Earth's crust as a consequence of the fluctuating extent of ice-sheet masses was accompanied by earthquakes probably due to local reactivation of pre-existing faults. Our study of a glacilacustrine and glacifluvial succession exposed on Rügen Island (SW Baltic Sea) indicates that some of the soft-sediment deformation structures within the succession must have formed shortly before the front of the Pleistocene Scandinavian Ice Sheet reached the study area (during the Last Glacial Maximum), thus during a stage of ice advance. Based on analysis of the textural and structural features of the soft-sediment deformation structures, the deformed layers under investigation are interpreted as seismites which formed as a result of seismically induced liquefaction and fluidisation. 


\section{Introduction}

Bending of the Earth's lithosphere and mantle displacement can be induced by loading-unloading cycles resulting from alternating advances and retreats of an ice sheet (see, e.g. Mörner, 1990). Such glacial isostatic adjustment (GIA) may well induce earthquakes in the Earth's crust that leave traces in the form of layers with soft-sediment deformation structures (SSDSs) called "seismites" (van Loon, 2009). The link between deglaciation and neotectonics was described by many authors, e.g. Johnston (1996), Muir-Wood (2000), Kaufmann et al. (2005), Brandes et al. (2012), Hoffmann and Reicherter (2012), van Loon and Pisarska-Jamroży (2014), and van Loon et al. (2016). In contrast, there is only little evidence that the ice-sheet advance could cause earthquakes, too (Brandes et al., 2011; Pisarska-Jamroży et al., 2018a, 2019), and that corresponding SSDSs of seismic origin have been formed.

Pisarska-Jamroży et al. (2018a) documented two layers with abundant SSDSs in a glacilacustrine silty-sandy succession, in a coastal cliff near Dwasieden on Jasmund Peninsula

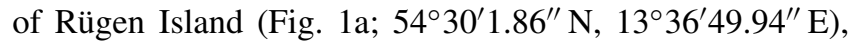
which have been interpreted as seismites. The location under study is situated at the southernmost rim of the TransEuropean Suture Zone (TESZ). The TESZ is a zone of crustal weakness and is characterised by numerous faults activated and reactivated during several late Palaeozoic and Mesozoic tectonic phases. The NW-trending faults (Fig. 1b, c) of the Tornquist Zone (Berthelsen, 1992), subdivided into the Sorgenfrei-Tornquist Zone (STZ) and the TornquistTeisseyre Zone (TTZ), and of the Tornquist Fan, occur in the area between Rügen and Bornholm (Thybo, 2000). Mesozoic transtension above the TESZ led to the formation of the Western Pomeranian Fault System (Krauss and Mayer, 2004). Compressional tectonics during the Late Cretaceous and the early Tertiary caused fault reactivation and anticline formation. Tertiary sediments are only locally preserved in graben structures bordered by WNW-ESE- to NWSE-trending faults of the Western Pomeranian Fault System. This suggests reactivation of this fault system during the Cainozoic (particularly during the Oligocene-Miocene) due to changes in the stress field (compression) from NE to NW (Seidel et al., 2018).

\section{Soft-sediment deformation structures interpreted as seismites}

The succession of the cliff in Dwasieden, with an overall height of $20 \mathrm{~m}$, is composed of Late Cretaceous (Early Maastrichtian) limestone overlain by five late Pleistocene units: three glacial diamict layers (M1-M3), separated from each other by glacifluvial and glacilacustrine silts, sands and gravels (see Brumme et al., 2019). Within the sandy silts, three deformed layers comprising SSDSs have been described (Fig. 2) by Pisarska-Jamroży et al. (2018a). The lowermost deformed level takes irregular positions; the SSDSs within it are concentrated in a few places, without any obvious lateral or vertical alignment. The top of this layer was exposed to periglacial conditions, which is indicated by the presence of an ice-wedge cast (Fig. 2c). Two deformed levels higher up show entirely different characteristics regarding both their distribution (laterally continuous over $150 \mathrm{~m}$ and vertically restricted to relatively thin levels) and structural nature; most SSDSs are relatively simple load casts and pseudonodules, with genetically related flame and fluid-escape structures (Fig. 2). A critical feature is that the two deformed levels are interbedded between undeformed layers. This excludes an origin of the deformations as a direct result of endogenic tectonics, periglacial processes or glacitectonics. A seismically induced origin of the SSDSs due to a GIA is therefore the only feasible explanation.

Some metres west of the main investigated profile, dumpstones and dropstones up to $0.8 \mathrm{~m}$ in size occur in the silty-sandy late Weichselian glacilacustrine succession. The dumping events are linked to iceberg rafting in a glacial lake (see Pisarska-Jamroży et al., 2018b).

\section{Age and origin of the seismites}

Based on their stratigraphic position and optically stimulated luminescence (OSL) dating, the two layers with SSDSs interpreted as seismites (Pisarska-Jamroży et al., 2018a) were deposited between $22.7 \pm 1.9 \mathrm{ka}$ and $19.0 \pm 1.8 \mathrm{ka}$, and were formed in front of the Scandinavian Ice Sheet (SIS) (Heine et al., 2009; Kenzler et al., 2015, 2017). Kenzler et al. (2017) concluded that the first late Weichselian ice advance reached the Jasmund Peninsula at $22 \pm 2 \mathrm{ka}$ (Fig. 3a). This time roughly coincides with the maximum extent of the SIS in the SW Baltic Sea area during the Brandenburg Phase of the Weichselian glaciation (Houmark-Nielsen, 2010; Hughes et al., 2016). The lowermost till (M1) is interpreted to have formed during the Saalian glaciation during MIS 6, whereas the rest of the succession accumulated during the Weichselian glaciation (MIS 4-2; Panzig, 1995; Kenzler et al., 2015).

The study area is situated in a low-seismicity intraplate setting, which raises the question of which type of faulting may have resulted in the earthquakes that caused the formation of the seismites. Among the faults on Rügen Island, which are most likely to have been (re)activated by GIA during the Pleistocene, the NW-trending Schaabe fault (Fig. 1c) is situated only $2 \mathrm{~km}$ away from the studied cliff section. The fault strikes parallel to the ice margin of the advancing SIS at a distance of a few tens of kilometres and could easily have been (re)activated because of considerable slip variations in the moat area (Fig. 3b), as suggested by numerical model results of Hampel and Hetzel (2006). However, other nearby faults like the Parchow, Lietzow or Nord-Jasmund, Boldewitz, and Wiek faults (Fig. 1c) could also be related to GIA. 


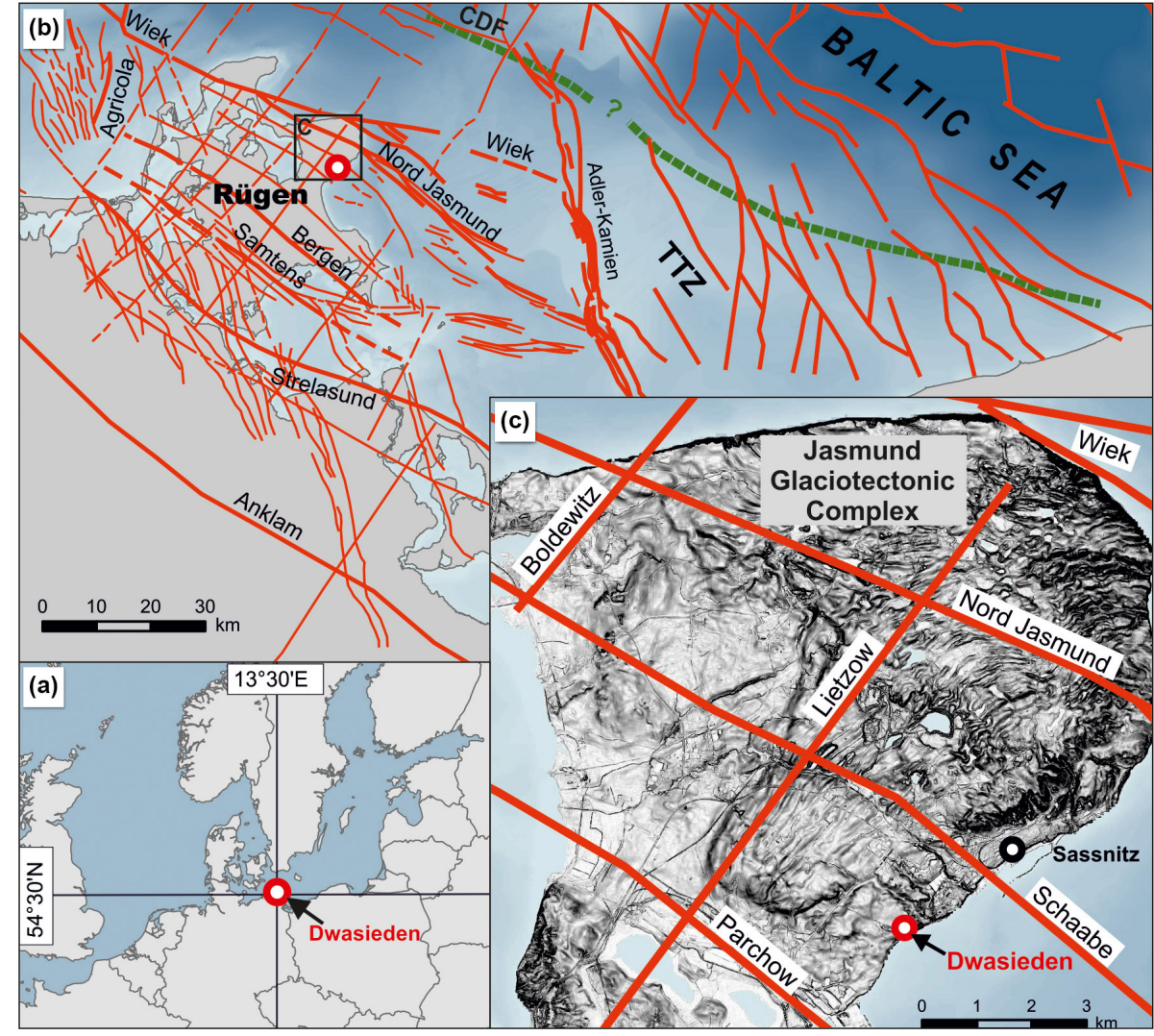

Figure 1. Location of the study area (modified from Pisarska-Jamroży, 2018a). (a) Position of Rügen Island within NW Europe. (b) Faults of the Tornquist Zone and Tornquist Fan recognised on Rügen Island and its vicinity (red lines); CDF: Caledonian Deformation Front (green dashed line); TTZ: Tornquist-Teisseyre Zone. (c) Rügen Island with main deep-rooted faults (Seidel et al., 2018, and references therein).

The GIA influence on the reactivation of the Schaabe fault has been tested with a three-dimensional finite-element model. As an ice load history model, the latest version of ANU-ICE was used (Lambeck et al., 2010), while several Earth model setups suggested for Fennoscandia (see Brandes et al., 2018) were tested. We analysed the Coulomb failure stress $(\delta \mathrm{CFS})$ of each GIA model, which, put simply, shows for values above zero that fault (re)activation is possible, while below zero earthquakes solely due to GIA can be excluded (see Brandes et al., 2012, 2018). We assume optimal conditions, i.e. that the fault parameters including frictional behaviour are ideally placed in a given tectonic stress regime. In the case of northern Germany, a compressional regime (thrust faulting) is suggested in the World Stress Map (Heidbach et al., 2018).

At Dwasieden, fault instability is indicated after $16 \mathrm{ka}$ (Fig. 4a), depending on the Earth model setup. However, in view of OSL dating results, the seismites could not be linked to stress changes induced by GIA - at ca. $23 \mathrm{ka}$, about $2 \mathrm{MPa}$ difference in $\delta \mathrm{CFS}$ must be overcome to reach the instability zone. Changes in pore-fluid pressure in the upper crust during that time (not tested here), e.g. due to increased meltwater, may decrease this difference, but likely not completely. Hence, we also investigated a strike-slip tectonic stress regime, which cannot be completely excluded according to the World Stress Map (Heidbach et al., 2018) and because the regional geology is complex so that the overall stress field could be locally altered. For a strike-slip regime all tested models reach the instability zone between 24.5 and $23.5 \mathrm{ka}$ (Fig. 4b), which supports a glacially induced origin of the seismites. We note though that these results are preliminary and subject to many assumptions and model uncertainties. The ice model has, for instance, no uncertainty assigned and has coarse 1000-year time steps during our period of interest. Further, the $\delta$ CFS calculation does not yet allow the analysis of oblique-slip faults. The $\delta$ CFS of such faulting could be found in between those for thrust and strike-slip faulting. Hence, thoroughly investigated and dated seismites such as at Dwasieden can help in GIA modelling by excluding or supporting certain GIA model setups, in historic icesheet development and in regional stress-field investigations.

Data availability. No data sets were used in this article. 

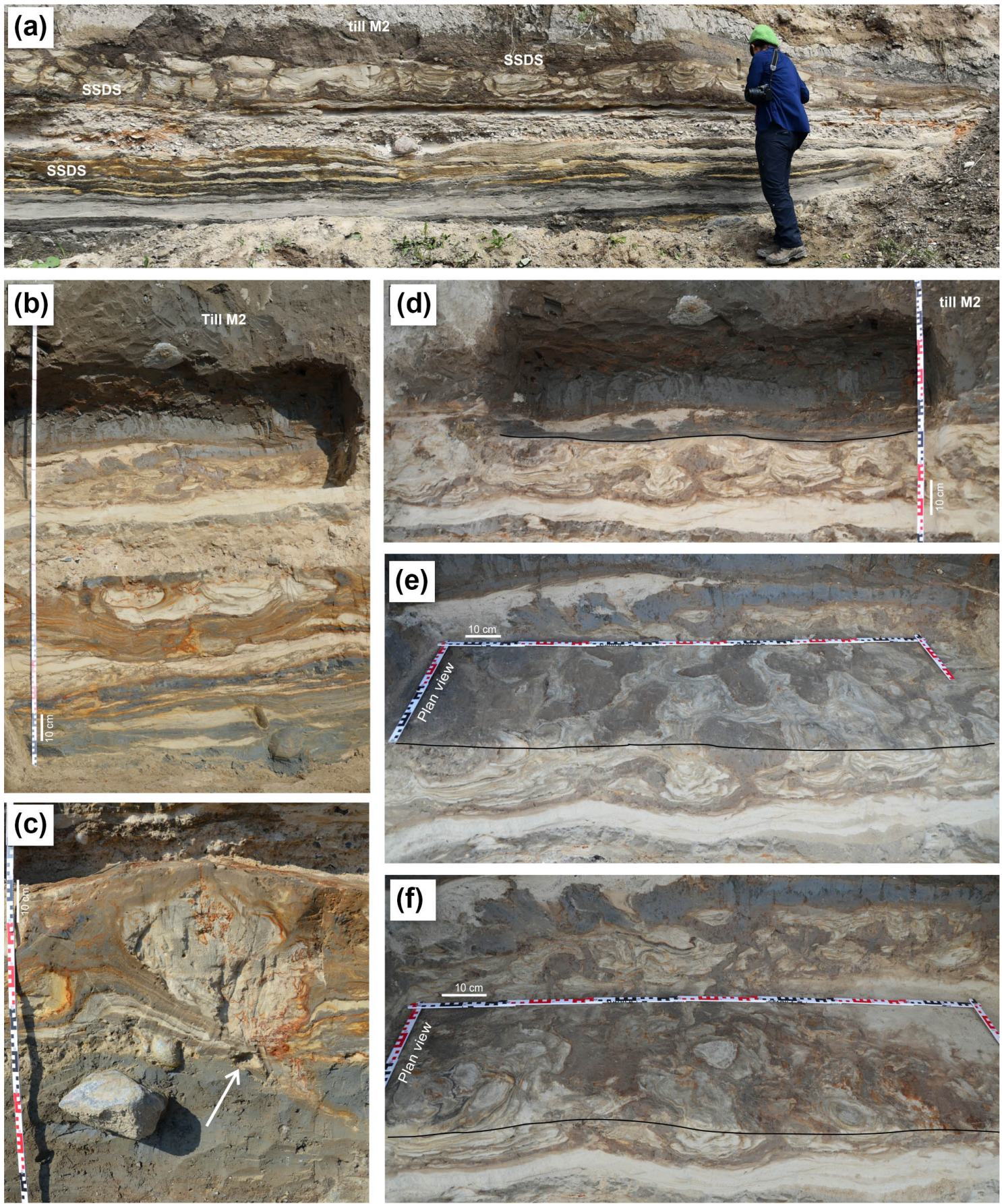

Figure 2. Details of the cliff section near the castle of Dwasieden. (a) The lateral extent of the soft-sediment deformation structures. (b) Vertical succession of the sediments below the till (M2) deposited during the Frankfurt/Brandenburgian advance of the SIS. The lowermost part contains glacilacustrine sediments with two dropstones; the upper part contains periglacially deformed sediments and deformations caused by seismic shocks. (c) Ice-wedge cast (white arrow) in the irregularly deformed sediments below the seismites. (d) Details of soft-sediment deformation structures. The yellowish sediments consist of silty fine-sandy material; the brownish sediments consist of silty clay and clayey silt. Sandy load casts and silty flame structures occur in the lower part of deformed layer. (e-f) Evolution of load structures in 3-D view using horizontal slicing of deformed layers. 


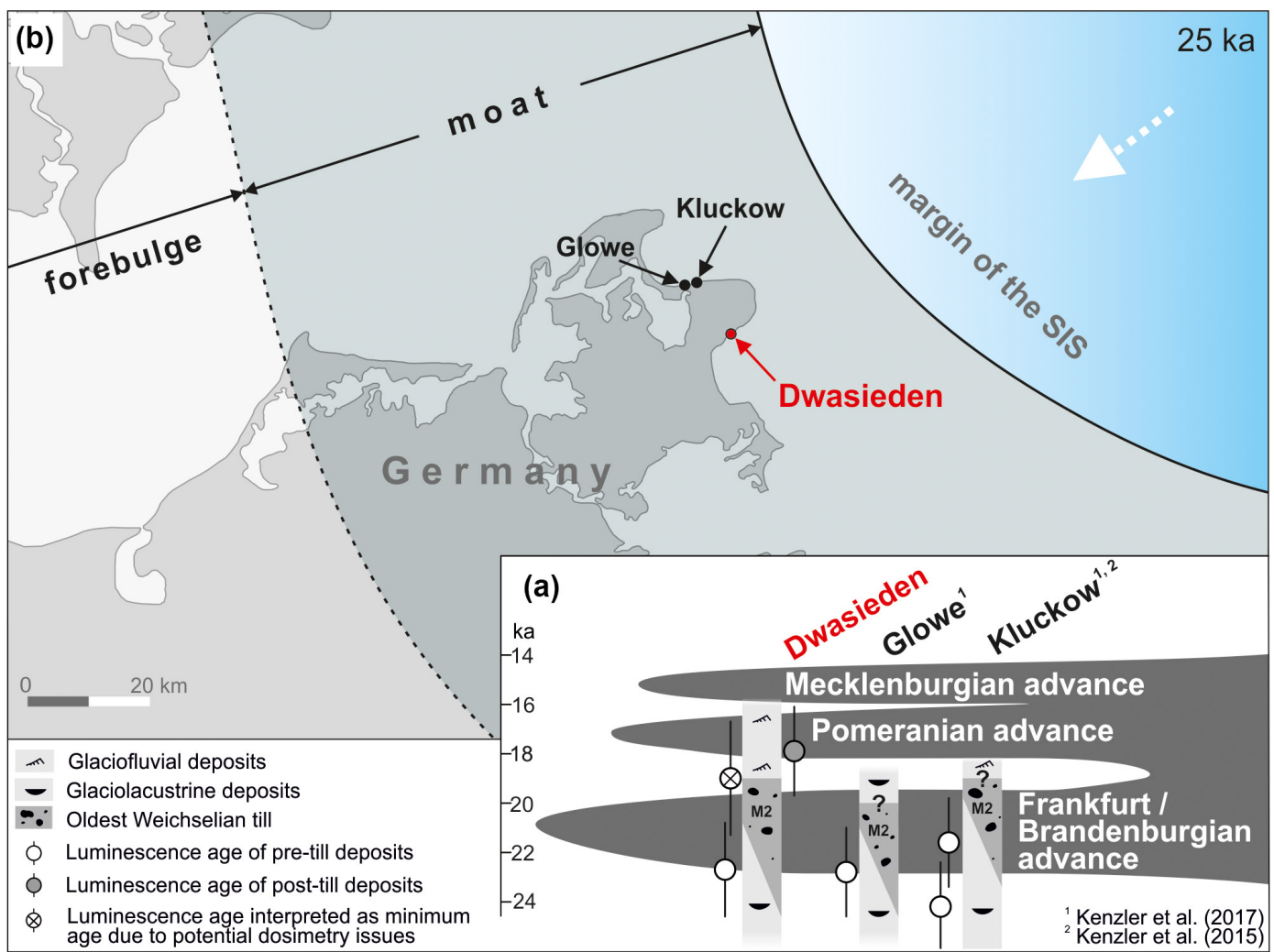

Figure 3. Palaeogeographical and lithostratigraphical reconstruction (modified from Pisarska-Jamroży, 2018a). (a) Luminescence ages of glacifluvial and glacilacustrine deposits below and above the first late Weichselian till (M2) on the Jasmund Peninsula in comparison to advances of the SIS. (b) Palaeogeographical map of the southwestern Baltic Sea area with the most likely extent of the SIS at $25 \mathrm{ka}$ (based on Hughes et al., 2016), and reconstructed positions of the moat and the forebulge (based on the Peltier et al., 2015 model).

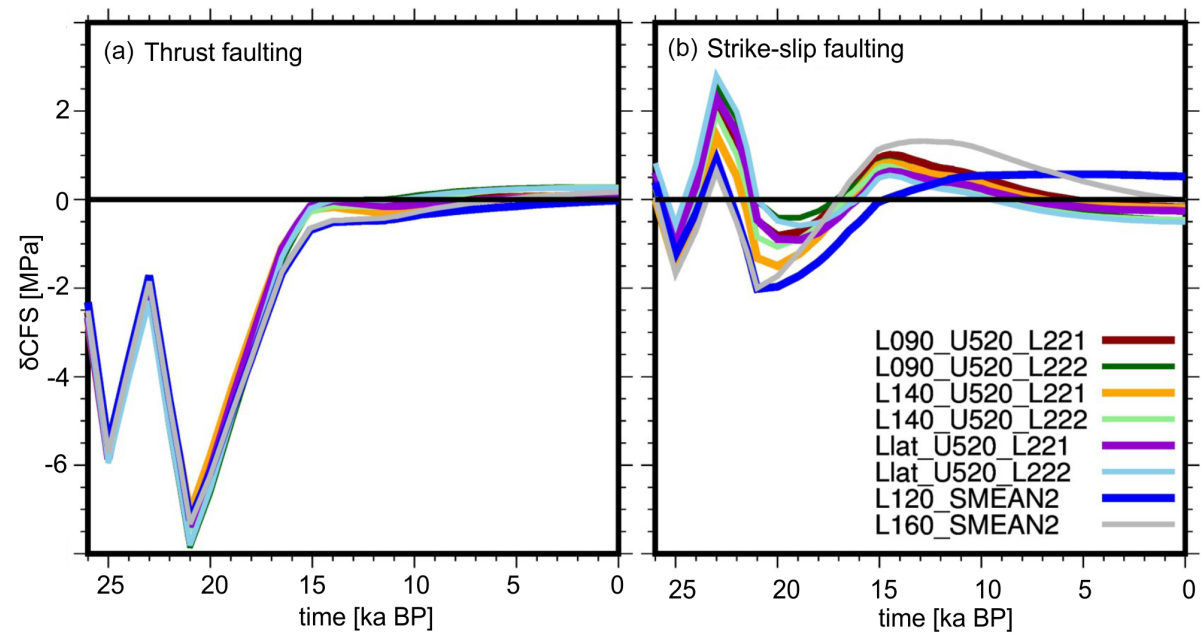

Figure 4. Changes in Coulomb failure stress ( $\delta$ CFS) at Dwasieden for (a) thrust and (b) strike-slip faulting over time for the last 26 kyr. The coloured curves represent eight different rheology models suitable for Fennoscandia (Brandes et al., 2018). $\delta$ CFS values above zero indicate fault instability. 
Author contributions. All authors discussed the results and contributed to the final paper. MPJ, SB, AB, GH, HH, MK, KO, HR and TVL participated in the fieldwork. HS and RS tested the GIA influence on the reactivation of faults with a three-dimensional finiteelement model.

Competing interests. The authors declare that they have no conflict of interest.

Acknowledgements. We would like to thank Oxana Lunina and Piotr Paweł Woźniak for valuable comments. The study has been financially supported by a grant for the GREBAL project (no. 2015/19/B/ST10/00661) from the National Science Centre of Poland. We acknowledge support for the article processing charge from the DFG (no. 393148499) and the Open Access Publication Fund of the University of Greifswald.

Financial support. This research has been supported by the DFG (German Research Foundation, grant no. 393148499), the National Science Centre of Poland (grant no. 2015/19/B/ST10/00661) and the Open Access Publication Fund of the University of Greifswald.

\section{References}

Berthelsen, A.: From Precambrian to Variscan Europe, in: A Continent Revealed: The European Geotraverse, edited by: Blundell, D., Freeman, R., and Mueller, S., Cambridge University Press, Cambridge, 153-164, 1992.

Brandes, C., Polom, U., and Winsemann, J.: Reactivation of basement faults: interplay of ice-sheet advance, glacial lake formation and sediment loading, Basin Res., 23, 53-64, 2011.

Brandes, C., Winsemann, J., Roskosch, J., Meinsen, J., Tanner, D. C., Frechen, M., Steffen, H., and Wu, P.: Activity along the Osning Thrust in central Europe during the Lateglacial: Ice-sheet and lithosphere interactions, Quaternary Sci. Rev., 38, 49-62, 2012.

Brandes, C., Steffen, H., Sandersen, P. B. E., Wu, P., and Winsemann, J.: Glacially induced faulting along the NW segment of the Sorgenfrei-Tornquist Zone, northern Denmark: implications for neotectonics and Lateglacial fault-bound basin formation, Quaternary Sci. Rev., 189, 149-168, 2018.

Brumme, J., Hüneke, H., and Phillips, E.: Micromorphology and clast microfabrics of subglacial traction tills at the sea-cliff Dwasieden: evidence of polyphase syn- and post-depositional deformation, DEUQUA Spec. Pub., this volume, 2019.

Hampel, A. and Hetzel, R.: Response of normal faults to glacialinterglacial fluctuations of ice and water masses on Earth's surface, J. Geophys. Research, 111, B06406, 2006.

Heidbach, O., Rajabi, M., Cui, X., Fuchs, K., Müller, B., Reinecker, J., Reiter, K., Tingay, M., Wenzel, F., Xie, F., Ziegler, M. O., Zoback, M. L., and Zoback, M.: The World Stress Map database release 2016: Crustal stress pattern across scales, Tectonophysics, 744, 484-498, 2018.

Heine, K., Reuther, A. U., Thieke, H. U., Schulz, R., Schlaak, N., and Kubik, P. W.: Timing of Weichselian ice marginal positions in Brandenburg (northeastern Germany) using cosmogenic in situ Be-10, Z. Geomorphol. N.F., 53, 433-454, 2009.

Hoffmann, G. and Reicherter, K.: Soft-sediment deformation of Late Pleistocene sediments along the southwestern coast of the Baltic Sea (NE Germany), Int. J. Earth Sci., 101, 351-363, 2012.

Houmark-Nielsen, M.: Extent, age and dynamics of Marine Isotope Stage 3 glaciation in the southwestern Baltic Basin, Boreas, 39 , 343-359, 2010.

Hughes, A., Gyllencreutz, R., Lohne, Ø. S., Mangerud, J., and Svendsen, J. I.: The last Eurasion ice sheets - a chronological database and time-slice reconstruction, DATED-1, Boreas, 45, 1-45, 2016.

Johnston, A. C.: A Wave in the Earth, Science, 274, 735, 1996.

Kaufmann, G., Wu, P., and Ivins, E. R.: Lateral viscosity variations beneath Antarctica and their implications on regional rebound motions and seismotectonics, J. Geodynam., 39, 165-181, 2005.

Kenzler, M., Tsukamoto, S., Meng, S., Thiel, C., Frechen, M., and Hüneke, H.: Luminescence dating of Weichselian interstadial sediments from the German Baltic Sea coast, Quat. Geochronol., 30, 215-256, 2015.

Kenzler, M., Tsukamoto, S., Meng, S., Frechen, M., and Hüneke, H.: New age constraints from the SW Baltic Sea area - implications for Scandinavian Ice Sheet dynamics and palaeoenvironmental conditions during MIS 3 and early MIS 2, Boreas, 46, 34-52, 2017.

Krauss, M. and Mayer, P.: Das Vorpommern-Störungssystem und seine regionale Einordnung zur Transeuropäischen Störung, Z. Geol. Wissenschaft., 32, 227-246, 2004.

Lambeck, K., Purcell, A., Zhao, J., and Svensson, N.-O.: The Scandinavian ice sheet: from MIS 4 to the end of the last glacial maximum, Boreas, 39, 410-435, 2010.

Mörner, N. A.: Glacioisostatic and long term crustal movements in Fennoscandia with respect to lithospheric and atmospheric processes and properties, Tectonophysics, 176, 13-24, 1990.

Muir-Wood, R.: Deglaciation seismotectonics: a principal influence on intraplate seismogenesis at high latitudes, Quaternary Sci. Rev., 19, 1399-1411, 2000.

Panzig, W.-A.: The tills of NE Rügen - lithostratigraphy, gravel composition and relative deposition directions in the southwestern Baltic region, in: Glacial Deposits in North-East Europe, edited by: Ehlers, J., Kozarski, S., and Gibbard, P., Balkema, Rotterdam, 521-533, 1995.

Peltier, W. R., Argus, D. F., and Drummond, R.: Space geodesy constrains ice-age terminal deglaciation: The global ICE-6G_C (VM5a) model, J. Geophys. Res.-Sol. Ea., 120, 450-487, 2015.

Pisarska-Jamroży, M., Belzyt, S., Börner, A., Hoffmann, G., Hüneke, H., Kenzler, M., Obst, K., Rother, H., and van Loon, A.J.: Evidence from seismites for glacio-isostatically induced crustal faulting in front of an advancing land-ice mass (Rügen Island, SW Baltic Sea), Tectonophysics, 745, 338-348, 2018a.

Pisarska-Jamroży, M., Van Loon, A. J., and Bronikowska, M.: Dumpstones as records of overturning ice rafts in a Weichselian proglacial lake (Rügen Island, NE Germany), Geol. Q., 62, 917924, 2018b.

Pisarska-Jamroży, M., Belzyt, S., Bitinas, A., Jusienè, A., and Woronko, B.: Seismic shocks, periglacial conditions and glaciotectonics as causes of the deformation of a Pleistocene meandering river succession in central Lithuania, Baltica, 32, 63-77, 2019. 
Seidel, E., Meschede, M., and Obst, K.: The Wiek Fault Zone east of Rügen Island: Origin, tectonic phases and its relation to the TransEuropean Suture Zone, Geol. Soc. London Spec. Pub., 469, https://doi.org/10.1144/SP469.10, 2018.

Thybo, H.: Crustal structure and tectonic evolution of the Tornquist Fan region as revealed by geophysical methods, Bull. Geol. Soc. Denmark, 46, 145-160, 2000.

Van Loon, A. J.: Soft-sediment deformation structures in siliciclastic sediments: an overview, Geologos, 15, 3-55, 2009.
Van Loon, A. J. and Pisarska-Jamroży, M.: Sedimentological evidence of Pleistocene earthquakes in NW Poland induced by glacio-isostatic rebound, Sediment. Geol., 300, 1-10, 2014.

Van Loon, A. J., Pisarska-Jamroży, M., Nartišs, M., Krievāns, M., and Soms, J.: Seismites resulting from high-frequency, highmagnitude earthquakes in Latvia caused by Late Glacial glacioisostatic uplift, Journal of Palaeogeography, 5, 363-380, 2016. 